Brief Communication

\title{
When hunger is greater than the beak: Guira Tanager (Aves, Thraupidae) strategy to optimize frugivory
}

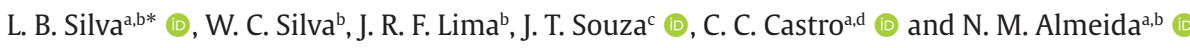 \\ aUniversidade Federal Rural de Pernambuco - UFRPE, Departamento de Biologia, Programa de Pós-graduação em Biodiversidade, Laboratório \\ de Ecologia Reprodutiva de Angiospermas, Recife, PE, Brasil \\ bUniversidade Estadual de Alagoas - UNEAL, Palmeira dos Índios, AL, Brasil \\ 'Universidade Estadual do Ceará - UECE, Faculdade de Educação, Ciências e Letras de Iguatu, Iguatu, CE, Brasil \\ dUniversidade Federal do Agreste de Pernambuco - UFAPE, Garanhuns, PE, Brasil
}

The use of tools was a determining factor for the biological and cultural evolution of the human species (Richerson and Boyd, 2006). The first studies addressing the use of tools by other animals in the context of food resource collection consider as "true" tools those that are detached from a substrate and held by the animal in the hand or mouth, as an extension of their bodies (Goodall, 1964). Several studies on this theme have mainly focused on manipulative animals with large brain capacity, such as several species of primates (Goodall, 1964; Moraes et al., 2014; Falótico et al., 2017).

Unlike mammals, birds do not have hands to manipulate a tool. Despite the fantastic ability to use the beak for the fabrication and "handling" of tools, displayed by members of the family Corvidae (Hunt, 1996; Rutz et al., 2007, 2010), records of this practice in other groups of birds are mainly associated with another category of tools, the "borderline", which include objects that are part of a substrate, such as anvils against which prey items are struck, baits that are deposited in water to attract fish, spines to hold food, among others (Hunt et al., 2002; Lefebvre et al., 2002).

However, obtaining observational data on these behaviors by birds in nature is still a challenge. In the Neotropical region, these records are scarce. Among them are the observations made by Sazima (2007). In his study, the author describes the use of baits by Butorides striata (Linnaeus, 1758) to attract fish. There are also observations on the use of a stone anvil by Taraba major (Vieillot, 1816) to break land snail shells made by Efe et al. (2015). Here, we present what appears to be the first record of tool use by Guira Tanager (Hemithraupis guira) (Linnaeus, 1766). We recorded the use of cavities in branches, which helped in the "handling" (holding or moving with the beak) of diaspores of Camboatã (Cupania oblongifolia) Mart. (Sapindaceae) during removal of arils in a Brazilian Atlantic Forest area.

The observations were made during a study on frugivory and seed dispersal by birds in the Pedra Talhada Biological Reserve, an area of Atlantic Forest covering about 4,000 ha, located between the states of Alagoas and Pernambuco in northeastern Brazil. During the month of January 2020, we carried out direct visual observation sessions between 6:00 am and 12:00 am in two Camboatã individuals in a forest edge area, totaling 12 hours of observations. We used $8 \times 32 \mathrm{~mm}$ binoculars and a photographic camera to record the behavior of the birds.

Guira Tanager is a species of the family Thraupidae that measures about $13 \mathrm{~cm}$ in total length and weighs about $10 \mathrm{~g}$. It has sexual dimorphism; the male has black head and throat sides while the female has olive head and yellowish chest. It is found throughout most of Brazil and is common on the edges of wet and dry forests. It feeds mainly on fruits and nectar (Sick, 1997).

Camboatã is an endemic tree of the Atlantic Forest that can reach about $20 \mathrm{~m}$ in height, occurring throughout the extension of this forest in Brazil. Its fruits are threewinged dehiscent capsules enclosing ellipsoid seeds with an orange aril, rich in lipids and proteins (Lorenzi, 1998).

During our observations, we considered a visit to be the period in which the bird arrived and remained feeding until leaving the plant or our field of vision. We collected beak width measurements from two adult individuals of Guira Tanager (one male and one female) from the ornithological collection of the UFPE. We also randomly collected 30 Camboatã seeds with aril for collection of morphometric data (length and width) with the aid of a digital caliper with a precision of $0.01 \mathrm{~mm}$.

We recorded a total of 26 visits by Guira Tanager to Camboatã. In 22 visits, the birds used a cavity in one of the plant's branches to support the seeds during the removal of the aril. When the beak width was smaller than or just as large as the seeds (Table 1 ), which could pose a limitation for handling and ingestion, the birds collected the diaspores and took them to a cavity surrounded by mosses in a branch of the Camboatã individual. Using this cavity, the birds were able to manipulate and remove the entire aril, without dropping the seeds to the forest ground. In total, we observed 58 processed seeds (Figure 1 ). The birds also showed the behavior of removing seeds that had already been processed from the cavity when there were between 5 and 7 seeds in there.

*e-mail: lb_silva@yahoo.com.br

Received: November 11, 2021 - Accepted: January 2, 2022 

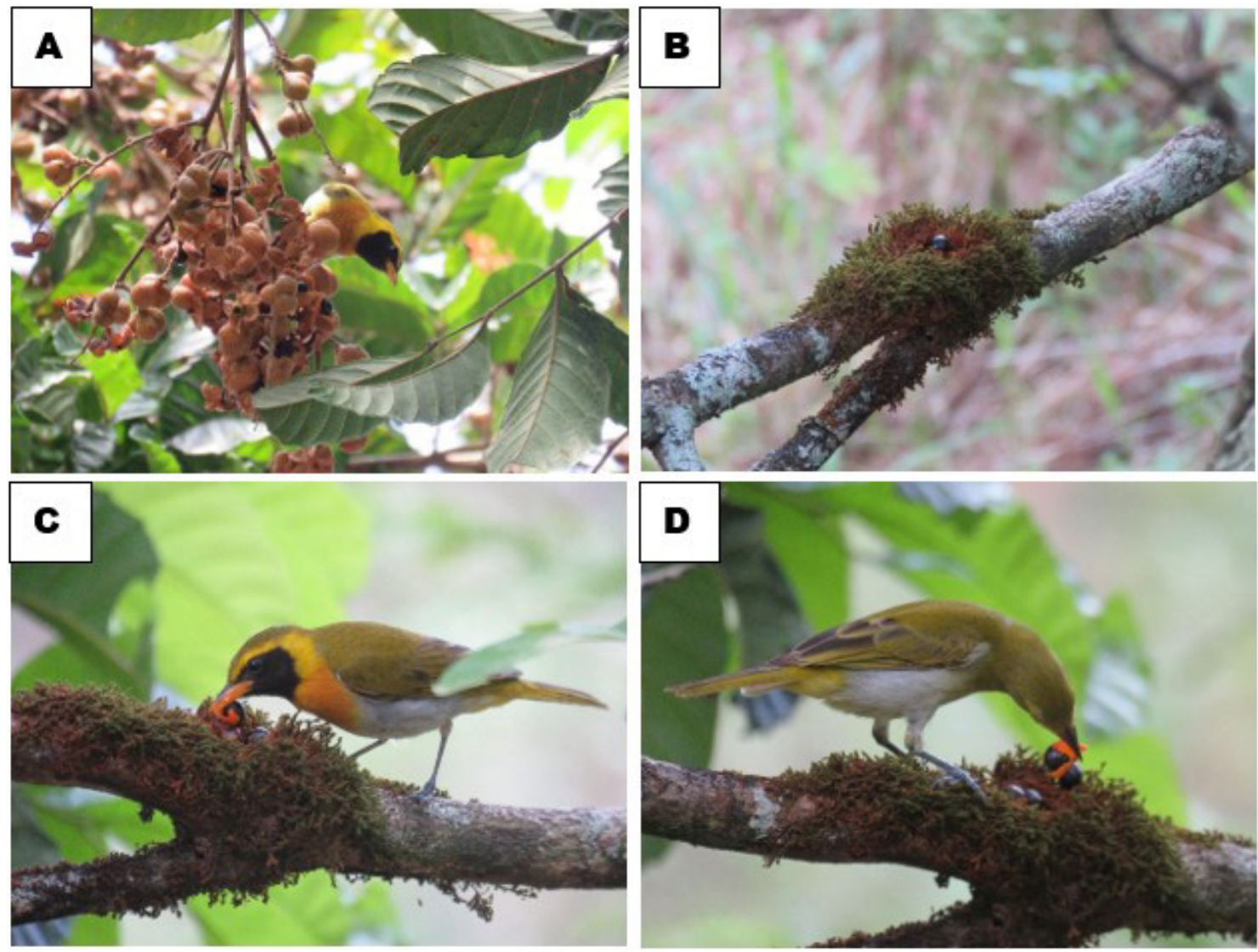

Figure 1. Use of branch cavities by Guira Tanager (Hemithraupis guira) to aid in the removal and ingestion of arils of Camboatã (Cupania oblongifolia) seeds in the Pedra Talhada Biological Reserve, northeastern, Brazil. (A) Male individual of Guira Tanager collecting Camboatã seeds; (B) Cavity used; (C) Male individual of Guira Tanager removing and ingesting the aril; (D) Female individual of Guira Tanager removing and ingesting the aril. Photos: Leonardo B. da Silva.

Table 1. Morphometry of Camboatã (Cupania oblongifolia) seeds and measures of beak width of Guira Tanager (Hemithraupis guira).

\begin{tabular}{cccccc}
\hline \multicolumn{2}{c}{ Seeds $(\mathbf{m m})$} & & \multicolumn{2}{c}{ Beak width $(\mathbf{m m})$} \\
\cline { 1 - 2 } \cline { 5 - 6 } Length & Width & & Male & Female \\
\hline $9.11 \pm 0.66$ & $7.41 \pm 0.44$ & & 7.71 & 7.18 \\
\hline
\end{tabular}

Most visits (84.61\%) were made by two individuals (couple). However, on one occasion, we observed the simultaneous visitation of two pairs, but one of them did not use the cavities to remove the arils. This same pair collected the diaspores and dropped them during manipulation, with no success in feeding. We observed that those individuals also consumed small pieces of aril without removing the seeds from the fruits.

In addition to having a small beak width, Guira Tanager belongs to a group of birds known as mashers, which are more efficient in exploiting small diaspores (about $4 \mathrm{~mm}$ in diameter) (Levey, 1987). Low food availability or nutritional advantage may be ecological factors that motivated the use of tools instead of conventional foraging techniques (Rutz et al., 2010). In fact, in the period of our observations, few ornithochoric species (with diaspores attractive to avifauna) had their fruits dispersed, and all had diaspores above $4 \mathrm{~mm}$, some with dimensions much larger than the beak of Guira Tanager, as for example Vitex polygama Cham. (about $15 \mathrm{~mm}$ ), Talisia sp. (about $10 \mathrm{~mm}$ ), and Byrsonima sericea DC. (about $10 \mathrm{~mm}$ ).

Diaspore size can represent a barrier to the foraging activity of birds. Larger diaspores are ingested and better utilized by birds that have larger beak width, which in turn disperse them by endozoochory (Silva and Tabarelli, 2000). However, the use of the cavity made it possible for the birds to completely remove and ingest the aril at all times. Although we observed that during the cleaning of the cavity, the seeds were dropped to the ground in the vicinity of the mother plant, which may hinder the establishment of new individuals (Santos et al., 2006). The use of this tool can also lead to the process of synzoochory (transport of diaspores) because the birds transported the seeds in their beak to be processed farther away from the plant of origin.

Guira Tanager birds live in pairs or in small groups that accompany mixed flocks during foraging activities (Sick, 1997). This behavior can favor learning processes among individuals. Thus, the use of cavities could be imitated or 
transmitted to new generations, as observed in species of the family Corvidae (Rutz et al., 2010).

In the Neotropical region, the ecological and evolutionary context, and the adaptive importance of tool use by birds are still poorly understood. Thus, valuable insights can be gained through studies that assess ecological processes such as frugivory and seed dispersal. Brazil has one of the greatest bird diversity in the world, and in the Atlantic Forest, many of them include fruits and seeds in their diets (Sick, 1997; Silva and Tabarelli, 2000). Monitoring the feeding behavior of these birds with a closer look can help us understand different questions, such as: what are the environmental pressures that favor the use of those tools? How is this ability transmitted to other individuals? How can the use of cavities influence ecological processes such as seed dispersal?

\section{Acknowledgements}

The authors thank the Coordenação de Aperfeiçoamento de Pessoal de Nivel Superior (CAPES) for financial support, Instituto Chico Mendes de Conservação da Biodiversidade (ICMBio) for allowing the study to be carried out in the area and Nordesta Reforestation \& Education for logistic support.

\section{References}

EFE, M.A., PAIVA, F.N., HOLDERBAUM, J.M. and LADLE, R.J., 2015. Rapid development of tool use as a strategy to predate invasive land snails. Journal of Ethology, vol. 33, no. 1, pp. 55-57. http:// dx.doi.org/10.1007/s10164-014-0412-6.

FALÓTICO, T., SIQUEIRA, J.O. and OTTONI, E.B., 2017. Digging up food: excavation stone tool use by wild capuchin monkeys. Scientific Reports, vol. 7, no. 1, pp. 6278. http://dx.doi.org/10.1038/ s41598-017-06541-0. PMid:28740211.

GOODALL, J., 1964. Tool-using and aimed throwing in a community of free-living chimpanzees. Nature, vol. 201, no. 4926, pp. 12641266. http://dx.doi.org/10.1038/2011264a0. PMid:14151401.

HUNT, G.R., 1996. Manufacture and use of hook-tools by New Caledonian crows. Nature, vol. 379, no. 6562, pp. 249-251. http://dx.doi.org/10.1038/379249a0.
HUNT, G.R., SAKUMA, F. and SHIBATA, Y., 2002. New Caledonian crows drop candle-nuts onto rock from communally-used forks on branches. The Emu, vol. 102, no. 3, pp. 283-290. http:// dx.doi.org/10.1071/MU01037.

LEFEBVRE, L., NICOLAKAKIS, N. and BOIRE, D., 2002. Tools and brains in birds. Behaviour, vol. 139, no. 7, pp. 939-973. http:// dx.doi.org/10.1163/156853902320387918.

LEVEY, D.J., 1987. Seed size and fruit-handling techniques of avian frugivores. American Naturalist, vol. 129, no. 4, pp. 471-485. http://dx.doi.org/10.1086/284652.

LORENZI, H., 1998. Árvores brasileiras: manual de identificação e cultivo de plantas arbóreas nativas do Brasil. São Paulo: Plantarum.

MORAES, B.L.C., SOUTO, A.S. and SCHIEL, N., 2014. Adaptability in stone tool use by wild capuchin monkeys (Sapajus libidinosus). American Journal of Primatology, vol. 76, no. 10, pp. 967-977. http://dx.doi.org/10.1002/ajp.22286. PMid:24753103.

RICHERSON, P.J. and BOYD, R., 2006. Not by genes alone: how culture transformed human evolution. Chicago: University of Chicago Press.

RUTZ, C., BLUFF, L.A., WEIR, A.A.S. and KACELNIK, A., 2007. Video cameras on wild birds. Science, vol. 318, no. 5851, pp. 765. http://dx.doi.org/10.1126/science.1146788. PMid:17916693.

RUTZ, C., BLUFF, L.A., REED, N., TROSCIANKO, J., NEWTON, J., INGER, R., KACELNIK, A. and BEARHOP, S., 2010. The ecological significance of tool use in New Caledonian crows. Science, vol. 329, no. 5998, pp. 1523-1526. http://dx.doi.org/10.1126/ science.1192053. PMid:20847272.

SANTOS, B.A., MELO, F.P.L. and TABARELLI, M., 2006. Seed shadow, seedling recruitment, and spatial distribution of Buchenavia capitata (Combretaceae) in a fragment of the Brazilian Atlantic Forest. Brazilian Journal of Biology = Revista Brasileira de Biologia, vol. 66, no. 3, pp. 883-890. http://dx.doi.org/10.1590/S151969842006000500014. PMid:17119836.

SAZIMA, I., 2007. Frustrated fisher: geese and tilapias spoil baitfishing by the Green Heron (Butorides striata) in an urban park in Southeastern Brazil. Revista Brasileira de Ornitologia, vol. 15, no. 4, pp. 611-614.

SICK, H., 1997. Ornitologia brasileira. Rio de Janeiro: Nova Fronteira.

SILVA, J.M.C. and TABARELLI, M., 2000. Tree species impoverishment and the future flora of the Atlantic forest of northeast Brazil. Nature, vol. 404, no. 6773, pp. 72-74. http://dx.doi. org/10.1038/35003563. PMid:10716443. 